\title{
Вплив антиадгезивних гелів на основі гіалуронату натрію на формування інтраперитонеальних спайок в експерименті
}

\author{
М. Г. Мельниченко, В. О. Ситнікова, А. А. Квашніна
}

Одеський національний медичний університет

\section{Impact of antiadhesive gels, manufactured on the base of sodium gyaluronate, on formation of intraperitoneal adhesions in experiment}

\author{
M. G. Melnychenko, V. O. Sytnikova, A. A. Kvashnina \\ Odessa National Medical University
}

\section{Реферат}

Мета. Вивчити вплив антиадгезивних гелів (ААГ) на основі гіалуронату натрію на формування інтраперитонеальних спайок в експерименті.

Матеріали і методи. Дослідження проведено на 45 статевозрілих щурах (самцях і самках) лініiі Wistar масою тіла 200 - 250 г. На першому етапі створювали модель інтраабдомінального спайкоутворення, на другому - вивчали вплив ААГ на основі гіалуронату натрію на інтраабдомінальне спайкоутворення в асептичних умовах та в умовах інфікування. Результати. У тварин, яким після створення моделі інтраабдомінального спайкоутворення в умовах інфікування застосували локальну аплікацію концентрованого гелю (10 мг/мл) на основі гіалуронату натрію, спостерігали достовірно більш низькі показники тяжкості інтраабдомінального спайкоутворення (p < 0,01) за всіма шкалами оцінки. Повна обробка черевної порожнини ААГ істотно запобігала тяжкості і поширеності післяопераційних перитонеальних спайок $(\mathrm{p}<0,05)$. За наявності перитоніту тяжкість спайкового процесу була оцінена в середньому в 2,14 бала $(0 ; 5) 3 a$ шкалою Matoba, поширеність - в 1,0 бала (0; 2) за шкалою Hoffman, що також достовірно нижче у порівнянні 3 контрольною групою - відповідно 5,17 (3; 7$)$ та 2,17 (2; 3) бала.

Висновки. Аплікація гелю гіалуронату натрію в концентрації 10 мг/мл на ділянки перитонеального пошкодження $е$ ефективним способом профілактики післяопераційного інтраабдомінального спайкоутворення в експерименті. Зрошення черевної порожнини гелем гіалуронату натрію в концентрації 5 мг/мл зменшує тяжкість та поширеність післяопераційного спайкоутворення в асептичних умовах та за наявності перитоніту в експерименті. Локальна аплікація гелю гіалуронату натрію в концентрації 5 мг/мл не чинить статистично значущого пригнічення спайкоутворення.

ключові слова: антиадгезивні гелі; гіалуронат натрію; перитонеальні спайки; експеримент.

Abstract

Objective. To study the impact of antiadhesive gels (AAG), manufactured on base of sodium hyaluronate, on formation of intraperitoneal adhesions in experiment.

Materials and methods. The investigation was conducted on 45 mature male and female rats of a Wistar line owing $200-$ $250 \mathrm{gr}$ body mass. On the first stage a simulation model of intraabdominal adhesions production was created, and on the second one - the impact of AAG, manufactured on the base of sodium hyaluronate, on intraabdominal adhesion-production in aseptic conditions and conditions of infectioning was studied.

Resulys. In laboratory animals, to which after creation of simulation model of intraabdominal adhesions production in conditions of infectioning a local application of concentrated gel $(10 \mathrm{mg} / \mathrm{ml})$, manifactured on the base of sodium hyaluronate, was accomplished a trustworthily more lower indices of the intraabdominal adhesion-production severity $(p<0.01)$ were observed in accordance to the estimation scales. Complete processing of abdominal cavity with AAG have had essentially prevented severity and spreading of postoperative peritoneal adhesions $(\mathrm{p}<0.05)$. In presence of peritonitis the adhesive process severity was estimated at average in 2.14 points $(0 ; 5)$ in accordance to Matoba scale, spreading - in 1.0 point $(0 ; 2)$ in accordance to Hoffman scale, what also trustworthily lower than in comparison with a control group - accordingly $5,17(3 ; 7)$ and $2,17(2 ; 3)$ points. Conclusion. Application of gel, manufactured on base of sodium hyaluronate, in concentration $10 \mathrm{mg} / \mathrm{ml}$ on focuses of peritoneal damage constitutes an effective method of prophylaxis for postoperative intraabdominal adhesion-production in experiment. The abdominal cavity irrigation with gel, based on the sodium hyaluronate gel in concentration $5 \mathrm{mg} / \mathrm{ml}$, reduces a severity and prevalence of postoperative adhesion-production in aseptic conditions and in presence of peritonitis in experiment. Local application of gel, basing on sodium hyaluronate, in concentration $5 \mathrm{mg} / \mathrm{ml}$ do not cause a statistically significant inhibition of the adhesions production

Keywords: antiadhesive gels; sodium hyaluronate; peritoneal adhesions; experiment.

Число та обсяг операцій на органах черевної порожнини у дітей постійно збільшуються. Згідно з даними різних авторів, у 63 - 97\% пацієнтів, яким виконали абдомінальне хірургічне втручання, в післяопераційному періоді утворюються перитонеальні спайки [1 - 3], що призво- дить до розвитку таких загрозливих ускладнень, як спайкова кишкова непрохідність (КН), хронічний больовий синдром, зокрема синдром Кноха [3 - 5], порушення анатомо-топографічного розташування органів малого таза та їх функцій, та несе у собі ризик розвитку ектопічної 
вагітності [5, 6] та трубно-перитонеального фактора порушення репродуктивної функції у дівчат $[4,6,7]$.

Ураховуючи сучасні уявлення щодо профілактики післяопераційного спайкоутворення та суперечливі літературні дані про недосконалість наявних заходів [8 - 10], а також накопичений позитивний досвід інтраопераційного застосування антиадгезивних засобів у лікуванні дітей із запальними хірургічними захворюваннями органів черевної порожнини, ми вирішили дослідити вплив гелю на основі гіалуронату натрію з декаметоксином на розвиток спайок очеревини в експерименті.

Мета дослідження: вивчити вплив антиадгезивних гелів (ААГ) на основі гіалуронату натрію на формування інтраперитонеальних спайок в експерименті.

\section{Матеріали і методи дослідження}

Дослідження проведено на 45 статевозрілих щурах (самцях і самках) лінії Wistar масою тіла 200 - 250 г двома етапами. На першому етапі створювали модель інтраабдомінального спайкоутворення в асептичних умовах (1-ша серія) і в умовах інфікування (2-га серія), на другому етапі вивчали вплив ААГ на основі гіалуронату натрію на інтраабдомінальне спайкоутворення в асептичних умовах (1ша серія) і в умовах інфікування (2-га серія) у 28 щурів, які склали основну групу (ОГ), із них у 21 вивчали вплив ААГ на основі гіалуронату натрію на інтраабдомінальне спайкоутворення в асептичних умовах $\left(\mathrm{O}_{\text {ac }}\right), \mathrm{y} 7$ - в умовах інфікування $\left(О \Gamma_{\text {iн. }}\right)$. Контрольну групу склали 17 щурів, із них у 11 моделювали інтраабдомінальне спайкоутворення за розробленою методикою в асептичних умовах $\left(К \Gamma_{\text {ac }}\right)$, у 6 в умовах інфікування $\left(К \Gamma_{\text {iн }}\right.$ ). Втручання виконували під загальним знеболюванням внутрішньоочеревинним введенням розчину тіопенталу натрію з розрахунку $20-25$ мг/ кг. Підготовку тварин, всі інвазивні втручання, знеболювання та виведення тварин з експерименту здійснювали з дотриманням відповідних положень Закону України «Про захист тварин від жорстокого поводження», «Загальних етичних принципів експериментів на тваринах», ухвалених Першим Національним конгресом з біоетики (Київ, 2001 р.), та Етичного кодексу вченого України, ухваленого Національною академією наук України у 2009 р.

Для створення моделі інтраабдомінального спайкоутворення в асептичних умовах (1-ша серія) серозний покрив сліпої кишки та парієтальну очеревину в нижніх квадрантах зіскоблювали стерильною цервікальною щіточкою в напрямку вздовж кишки до появи точкових крововиливів у вигляді «кров'яної роси»; в умовах інфікування (2-га серія) - за 20 год до описаного пошкодження внутрішньоочеревинно вводили 2 мл суспензії фекалій у фізіологічному розчині натрію хлориду (10 мг подрібнених сухих фекалій у 50 мл). У післяопераційному періоді ці тварини отримували протягом 3 днів ін'єкцію цефтриаксону 3 розрахунку 100 мг/кг. Після операції за тваринами проводили спостереження.

У 1-й серії (асептичні умови) на другому етапі експерименту тварин ОГ ас. розподілили на три групи в залежності від складу ААГ та способу його аплікації: ОГ ${ }_{\text {ас. }} 1$ (n=7) - після зіскоблювання очеревини застосовували аплікацію гелю, до складу якого входили гіалуронат натрію 5 мг/мл та декаметоксин, на ділянки пошкодженого мезотелію; ОГ ас. 2 (n=7) - аплікацію гелю, до складу якого входили гіалуронат натрію 5 мг/мл та декаметоксин, застосовували на ділянки пошкодженого мезотелію та зрошували всю черевну порожнину гелем у кількості 50 мл/кг перед зашиванням лапаротомної рани; ОГ ас. $3(\mathrm{n}=7)$ - аплікацію гелю, до складу якого входив гіалуронат натрію 10 мг/ мл, застосовували на ділянки пошкодженого мезотелію.

У 2-й серії другого етапу експерименту у 7 тварин ОГ дослідили профілактичну дію ААГ в умовах інфікування: після санації черевної порожнини застосовували аплікацію гелю, до складу якого входили гіалуронат натрію 5 мг/мл та декаметоксин, з наступним зрошенням черевної порожнини. Для 2-ї серії експерименту було обрано саме цей варіант профілактики інтраабдомінального спайкоутворення, оскільки він був ефективним у першій серії у тварин ОГ ас. 2 та давав змогу обробити більшу площу ураженої очеревини, що, на наш погляд, доцільно за наявності перитоніту.

Тварин виводили з експерименту на 14-ту добу після втручання шляхом передозування тіопенталу натрію (3 розрахунку 100 мг/кг маси тіла). Інтраабдомінальне спайкоутворення досліджували макроскопічно та гістологічно. Для оцінки вираженості злукового процесу в черевній порожнині оптимальним було визнано U-подібний розріз, який уможливлював доступ до всіх відділів черевної порожнини та гарантоване непошкодження вісцеропарієтальних спайок, у тому числі і з післяопераційним рубцем (ПОР).

Макроскопічно вираженість післяопераційного спайкоутворення оцінювали за кількома критеріями: кількість, щільність та розповсюдженість спайоку різних відділах черевної порожнини, наявність васкуляризації тощо, використовуючи шкали Matoba [8] та Hoffman [11], розроблені саме для кількісної оцінки спайкоутворення у моделях з пошкодженням сліпої кишки, та визначали інтегральний показник.

Додатково оцінювали наявність спайок з ПОР, випоту в черевній порожнині, ознак КН.

Після макроскопічної оцінки спайкового процесу вилучали сліпу кишку конгломератами, що утворилися, або інтактну та проводили гістологічне дослідження отриманих зразків (світлова мікроскопія, забарвлення гематоксиліном і еозином та за ван Гізоном).

\section{Результати}

Протягом періоду спостереження тварини були активні, пересувалися і споживали їжу та рідину в об’ємах, які в усіх групах не відрізнялися. Загибелі тварин у післяопераційному періоді чи аутоканібалізму не спостерігали. Післяопераційна рана загоювалася без ускладнень на 4 - 5-й день первинним натягом. Поведінка тварин піддослідних груп не змінювалася протягом усього періоду спостереження.

За результатами макроскопічної оцінки на першому етапі експериментального дослідження 1-ї серії у однієї тварини відмітили формування двостволки між сліпою кишкою та дистальною петлею здухвинної кишки, що призвело до інтермітуючої КН, ще у одніеї тварини петля 
клубової кишки була завернута та припаяна з пасмом великого сальника до купола сліпої кишки, яка у свою чергу була залучена у зрощення з післяопераційною раною. Оцінюючи макроскопічно стан черевної порожнини у тварин 2-ї серії, ми виявили вісцеропарієтальні спайки також і у відділах черевної порожнини, де не зіскоблювали мезотелій, вірогідно вони утворилися внаслідок пошкодження, зумовленого дією патогенних бактеріальних факторів. Також відмітили наявність у 3 тварин вісцеровісцеральних спайок між сліпою кишкою та петлями тонкої кишки і сальником.

Гістологічним дослідженням отриманих зразків у тварин 1-ї і 2-ї серій виявлено фіксацію стінки сліпої кишки до черевної стінки щільною сполучної тканиною. У разі забарвлення за ван Гізоном у тканинах сальника та по периферії кишки спостерігали ділянки волокнистої сполучної тканини. Саме наявність та розповсюдженість вісцеропарієтальних спайок є основою для порівняння ефективності антиадгезивних засобів у запропонованому способі моделювання.

Узагальнивши результати обох серій першого етапу експериментального дослідження, ми дійшли висновку, що запропонований спосіб моделювання інтраабдомінальних спайок забезпечує розвиток адгезивного інтраабдомінального процесу, а внутрішньоочеревинне введення 2 мл суспензії фекалій у фізіологічному розчині натрію хлориду за 20 год до описаного пошкодження призводить до виникнення фібринозно-гнійного перитоніту з перитонеальними спайками. У всіх спостереженнях виявляли надлишкове інтраабдомінальне спайкоутворення, розвиток якого, на наш погляд, у 1-й серії був обумовлений механічним пошкодженням серози, у 2-й серії - як інфікуванням, так і травмуючою дією. Таким чином, формування інтраперитонеального спайкового процесу було досягнуто у 100\% піддослідних тварин.

Створення адгезивних моделей слугувало основою для проведення другого етапу дослідження. Макроскопічно на другому етапі у тварин 1-ї серії спайкоутворення між петлями кишечника не було, в умовах інфікування спостерігали незначну кількість площинних зрощень, відмежування запальної інфільтрації між кишкою та сальником, очеревина була тьмяна, кількість випоту незначна, прохідність кишечника не порушена.

Гістологічна картина у тварин 1-ї серії була такою: тканина кишечника звичайного складу, судини всіх прошарків кишки та брижі помірно повнокровні, явища стазу в окремих судинах, брижа містить тонкі колагенові волокна. У разі інфікування черевної порожнини (2-га серія) гістологічно у тварин тканини брижі та кишки інфільтровані сегментоядерними нейтрофільними лейкоцитами, судини розширені, повнокровні, стаз, осередки некрозу у брижі, прошарки сполучної тканини в підслизовій основі.

Для оцінки статистичної значущості відмінностей між досліджуваними групами тварин використали непараметричний U-критерій Манна-Уітні. Вираженість спайкового процесу за шкалою Matoba у тварин КГ ас. оцінена в 4,91 бала, у тварин ОГ ас. 1 - у 4,43 бала (табл. 1), проте різниця між цими показниками статистично незначуща (Uкритерій 23,0; р > 0,05).

У тварин ОГ ас 3, яким застосовували локальну аплікацію концентрованого гелю (10 мг/мл), спостерігали статистично достовірно білыш низькі показники тяжкості інтраабдомінального спайкоутворення ( $<$ <,01) за всіма шкалами оцінки. Повна обробка черевної порожнини гелем з меншою концентрацією активного компонента (5 мг/мл) істотно запобігала утворенню тяжких і поширених післяопераційних перитонеальних спайок ( $<$ <0,05). За ефективністю застосування гелю між групами ОГ ас. 2 i ОГ 3 ас. 3 не було виявлено істотних переваг, тобто обидва способи є однаково ефективними в профілактиці післяопераційного спайкоутворення.

Залежність ефективності від способу застосування та концентрації ААГ вочевидь пов'язана із його в'язкістю та відповідно здатністю до утримання у місці аплікації протягом критичного періоду часу. Адже для ефективної профілактики зрощень пошкоджені перитонеальні поверхні мають бути розмежовані протягом часу, необхідного для регенерації очеревини (приблизно 72 год), що не може бути досягнуто у разі локальної аплікації більш рідкого за консистенцію низькоконцентрованого гелю, який має тенденцію до скупчення у відлогих місцях черевної порожнини під дією гравітації.

За наявності перитоніту (2-а серія) тяжкість спайкового процесу оцінена в 2,14 (0; 5) бала за шкалою Matoba, поширеність у 1,0 (0; 2) бала за шкалою Hoffman, що також достовірно нижче у порівнянні з відповідними показниками в К $\Gamma_{\text {ін. }}$ (табл. 2). Ускладнення з боку операційної рани розвинулись у однієї тварини КГ ін у вигляді підапоневротичного абсцесу, і у одніеї тварини КГ лась лігатурна нориця. За показниками загибелі тварин, явищ КН у цій серії експерименту відмінності між групами були статистично незначущими.

\begin{tabular}{|c|c|c|c|c|c|c|c|c|c|c|c|}
\hline \multicolumn{2}{|c|}{ Таблиця 1.} & \multicolumn{10}{|c|}{$\begin{array}{l}\text { Результати макроскопічної (середні значення у балах) та додаткової (кількість тварин) оцінки } \\
\text { інтраабдомінального спайкоутворення в асептичних умовах }\end{array}$} \\
\hline \multirow[b]{3}{*}{ Група } & \multicolumn{7}{|c|}{ Шкала } & \multirow{2}{*}{\multicolumn{3}{|c|}{ Додаткова оцінка }} & \multirow{3}{*}{ 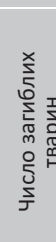 } \\
\hline & \multicolumn{3}{|c|}{ Matoba } & \multicolumn{4}{|c|}{ Hoffmann } & & & & \\
\hline & 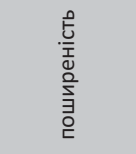 & 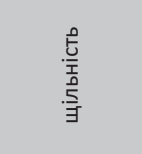 & $\begin{array}{c}\sum_{0}^{\Sigma} \\
\substack{\pi \\
ٌ}\end{array}$ & 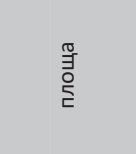 & 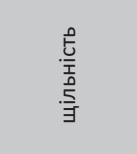 & 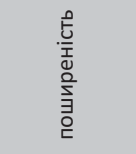 & 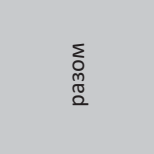 & 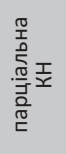 & 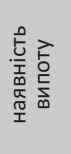 & 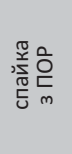 & \\
\hline $\mathrm{O}_{\mathrm{ac}} .1$ & $1,86(0 ; 3)$ & $2,57(2 ; 4)$ & $4,43(2 ; 6)$ & $2,14(1 ; 3)$ & $2,29(1 ; 3)$ & $1,86(1 ; 3)$ & $6,29(3 ; 8)$ & - & 1 & 1 & 1 \\
\hline $\mathrm{O}_{\mathrm{acc}}{ }^{2}$ & $1,14(0 ; 2)$ & $1,71(0 ; 3)$ & $2,85(0 ; 5)$ & $1,29(0 ; 2)$ & $1,43(0 ; 3)$ & $1,0(0 ; 2)$ & $3,72(0 ; 7)$ & - & 1 & 3 & - \\
\hline $\mathrm{O}_{\mathrm{acc}} 3$ & $0,86(0 ; 2)$ & $1,29(0 ; 3)$ & $2,15(0 ; 5)$ & $1,14(0 ; 2)$ & $1,29(0 ; 2)$ & $1,0(0 ; 2)$ & $3,43(0 ; 5)$ & - & - & 2 & - \\
\hline $\mathrm{K} \Gamma_{\mathrm{ac}}$ & $2,55(1 ; 3)$ & $2,36(1 ; 3)$ & $4,91(3 ; 6)$ & $2,91(1 ; 4)$ & $2,27(1 ; 3)$ & $2,0(1 ; 3)$ & $7,18(3 ; 10)$ & 2 & 2 & 3 & - \\
\hline
\end{tabular}




\begin{tabular}{|c|c|c|c|c|c|c|c|c|c|c|c|}
\hline Таблиця 2. & \multicolumn{11}{|c|}{$\begin{array}{l}\text { Результати макроскопічної (середні значення у балах) та додаткової (кількість тварин) оцінки } \\
\text { інтраабдомінального спайкоутворення за наявності перитоніту }\end{array}$} \\
\hline \multirow[b]{3}{*}{ Група } & \multicolumn{7}{|c|}{ Шкала } & \multirow{2}{*}{\multicolumn{3}{|c|}{ Додаткова оцінка }} & \multirow{3}{*}{ 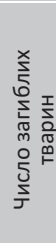 } \\
\hline & \multicolumn{3}{|c|}{ Matoba } & \multicolumn{4}{|c|}{ Hoffmann } & & & & \\
\hline & 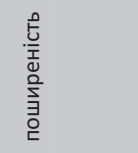 & 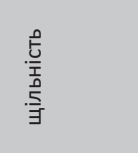 & 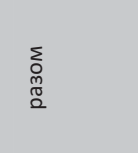 & $\stackrel{0}{\Xi}$ & 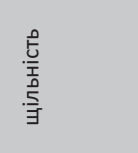 & 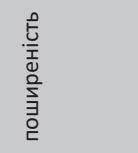 & 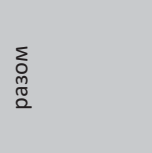 & 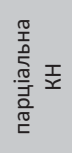 & 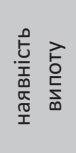 & 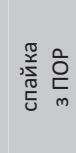 & \\
\hline ОГ Гн... & $0,86(0 ; 2)$ & $1,29(0 ; 3)$ & $2,14(0 ; 5)$ & $1,57(0 ; 3)$ & $1,14(0 ; 2)$ & $1,0(0 ; 2)$ & $3,71(0 ; 7)$ & - & 6 & 3 & 1 \\
\hline $\mathrm{K} \Gamma_{\text {iн. }}$ & $2,33(2 ; 3)$ & $2,83(1 ; 4)$ & $5,17(3 ; 7)$ & $2,67(1 ; 4)$ & $2,33(2 ; 3)$ & $2,17(2 ; 3)$ & $7,17(5 ; 10)$ & - & 5 & 3 & 1 \\
\hline
\end{tabular}

Узагальнені результати обох серій експериментального дослідження дають підстави для висновку, що ААГ на основі гіалуронату натрію зменшують вираженість і поширеність післяопераційного спайкоутворення як в асептичних умовах, так і за наявності перитоніту, однак їх ефективність залежить як від способу застосування, так і від концентрації активного компонента, яка безпосередньо впливає на здатність гелю до тривалого утримання в місці аплікації та на його бар'єрні властивості. Найбілыш ефективним було локальне використання концентрованого гелю (10 мг/мл) або заповнення всієі черевної порожнини менш концентрованим гелем ( 5 мг/мл). Останній спосіб також є доцільним за наявності перитоніту, адже уможливлює обробку більшої поверхні пошкодженої очеревини. Ефективність локального застосування гіалуронату натрію в низькій концентрації з метою профілактики спайкоутворення не відрізнялася статистично значущо від показника контрольної групи.

\section{Обговорення}

На сьогодні немає універсального способу інтраопераційної профілактики інтраабдомінальних спайок в асептичних умовах та за наявності перитоніту. Тому, вивчаючи вплив ААГ на основі гіалуронату натрію на формування інтраперитонеальних спайок в експерименті, ми моделювали спайковий процес, який виникає після хірургічних втручань та може бути стандартизований і відтворений в експериментальних умовах. Вважаємо за необхідне наголосити, що ефективність запропонованого способу профілактики інтраабдомінальних спайок в асептичних умовах та за наявності перитоніту шляхом використання ААГ на основі гіалуронату натрію залежить як від способу застосування, так і від концентрації активного компонента, що впливає на здатність гелю до тривалого утримання в місці аплікації та на його бар'єрні властивості. Отримані дані дають підстави вважати можливим проведення клінічних досліджень застосування ААГ з метою профілактики інтраабдомінального спайкоутворення у дітей після хірургічних втручань на органах черевної порожнини.

\section{Висновки}

1. Аплікація гелю гіалуронату натрію в концентрації 10 мг/мл на ділянки перитонеального пошкодження є ефективним способом профілактики післяопераційного інтраабдомінального спайкоутворення в експерименті.

2. Зрошення черевної порожнини гелем гіалуронату натрію в концентрації 5 мг/мл зменшує тяжкість та по- ширеність післяопераційного спайкоутворення в асептичних умовах та за наявності перитоніту в експерименті.

3. Локальна аплікація гіалуронату натрію в концентрації 5 мг/мл не чинить статистично значущого пригнічення спайкоутворення.

\section{References}

1. Sopuev AA, Mamatov NN, Ovcharenko KE. Otcenka effektivnosti razlichnykh variantov modelirovaniia spaechnogo protcessa briushnoi polosti. Aktualnye problemy gumanitarnykh i estestvennykh nauk. 2011;(3):327-32. [In Russian].

2. Arung W, Meurisse M, Detry O. Pathophysiology and prevention of postoperative peritoneal adhesions. World Journal of Gastroenterology [Internet]. 2011Nov7;17(41):4545-53. Available from: https://www.wjgnet com/1007-9327/full/v17/i41/4545.htm. doi: 10.3748/wjg.v17.i41.4545.

3. Fredriksson F, Christofferson R, Carlsson P, Lilja H. Locally increased concentrations of inflammatory cytokines in an experimental intraabdominal adhesion model. Journal of Pediatric Surgery. 2014;49(10):1480-4. doi: 10.1016/j.jpedsurg.2014.03.010.

4. Lipatov VA. Obosnovaniye primeneniya gelya metiltsellyulozy dlyaprofilaktiki posleoperatsionnogo spayechnogo protsessa bryushnoy polosti. PhD [Thesis], Kursk; 2004. 28 p. [In Russian].

5. Ahmad G, Oflynn H, Hindocha A, Watson A. Barrier agents for adhesion prevention after gynaecological surgery. Cochrane Database of Systematic Reviews [Internet]. 2015 Apr 30 [cited 2018 Aug 29]; Available from: http://cochranelibrary-wiley.com/doi/10.1002/14651858.CD000475. pub3/full. doi: 10.1002/14651858.CD000475.pub3.

6. Mayes SA. Hyaluronic acid and alginate blend hydrogel films for the prevention of postsurgical adhesions [dissertation on the internet]. The University of Texas at Austin, USA; 2013. Retrieved from Texas Scholar works database. Available from: http://hdl.handle.net/2152/22058.

7. Morse Abraham N, Hammer Robert A, Cornella Jeffrey L, Loftus Joseph C. Validation of a Mouse Adhesion Reduction. Model Using Seprafilm ${ }^{\circledR}$. Meyers Primary Care Institute Publications and Presentations; 2006. 377 p. Available from: http://escholarship.umassmed.edu/meyers_pp/377.

8. Matoba M, Hashimoto A, Tanzawa A, Orikasa T, Ikeda J, Iwame Y, et al. Prevention of Polyglycolic Acid-Induced Peritoneal Adhesions Using Alginate in a Rat Model. BioMed Research International [Internet]. 2015;2015:1-16. Available from: http://dx.doi.org/10.1155/2015/403413. doi: $10.1155 / 2015 / 403413$.

9. Kraemer B, Wallwiener C, Rajab TK, Brochhausen C, Wallwiener M, Rothmund R. Standardised Models for Inducing Experimental Peritoneal Adhesions in Female Rats. BioMed Research International [Internet]. 2014;2014:1-8. Available from: http://dx.doi.org/10.1155/2014/435056. doi: $10.1155 / 2014 / 435056$.

10. Wu Q, Wang N, He T, Shang J, Li L, Song L, et al. Thermosensitive hydrogel containing dexamethasone micelles for preventing postsurgical adhesion in a repeated-injury model. Scientific Reports [Internet]. 2015Jan;5(1). Available from: https://www.ncbi.nlm.nih.gov/ pubmed/26324090. doi: 10.1038/srep13553.

11. Hoffmann NE, Siddiqui SA, Agarwal S, Mckellar SH, Kurtz HJ, Gettman MT, et al. Choice of Hemostatic Agent Influences Adhesion Formation in a Rat Cecal Adhesion Model. Journal of Surgical Research. 2009;155(1):77-81. doi: 10.1016/j.jss.2008.08.008. 